\title{
Implementasi Algoritma Sequential dan Welch Powell phsada Pewarnaan Graf (Studi Kasus Pewarnaan Peta Kota Makassar)
}

\author{
Muhammad Ammar \\ Universitas Muhammadiyah Bulukumba \\ Tanah Kongkong, Ujung Bulu, Kabupaten Bulukumba, Sulawesi Selatan 92511 \\ Email: ammar.uin@gmail.com
}

\begin{abstract}
The aim of this research is how to implement Sequential algorithm and Welch Powell algorithm on graph coloring, especially on Makassar city map coloring. The research method used was a case study aimed at searching information in the form of a map of Makassar city. The first step is to take a colored map of Makassar city at the Dinas tata ruang kota makassar, then redraw it with the help of Corel Draw X7 software, so there are no colors. The next step is to represent the map in graph form by taking the region (sub-district) as a node and then doing graph coloring using Sequential algorithm and Welch Powell algorithm. The results of coloring the Makassar city map using Sequential algorithm and Welch Powell algorithm, both produce chromatic numbers $\chi(G)=4$ or the number of colors produced to color a graph there are 4 colors. The colors used are red, yellow, green and blue. Then from the results of coloring this graph can easily be applied to color the map of the city of Makassar based on the coloring requirements obtained. Because it has the same chromatic numbers, it can be concluded that the Sequential algorithm is no better than the Welch Powell algorithm, or vice versa the Welch Powell algorithm is no better than the Sequential algorithm for the case of coloring the Makassar city map. The previous Makassar city map coloring or without the algorithm, produces chromatic numbers $\chi(G)=12$ or the number of colors produced to color a graph there are 12 colors. So that the two algorithms are much better at coloring than the previous Makassar city map coloring or without the algorithm
\end{abstract}

Keywords: Graph, Graph Coloring, Sequential Algorithm, Welch Powell Algorithm, Chromatic Numbers

\begin{abstract}
Abstrak
Tujuan dari penelitian ini adalah bagaimana mengimplementasikan algoritma Sequential dan algoritma Welch Powell pada pewarnaan graf khususnya pada pewarnaan peta kota Makassar. Metode penelitian yang digunakan adalah studi kasus yang bertujuan mengumpulkan informasi berupa peta kota Makassar. Langkah pertama yang dilakukan yaitu mengambil peta kota Makassar berwarna di Instansi Dinas tata ruang kota Makassar, kemudian digambar ulang dengan bantuan software Corel Draw X7, sehingga tidak terdapat warna. Langkah berikutnya yaitu merepresentasikan peta kedalam bentuk graf dengan mengambil daerah wilayah (kecamatan) sebagai simpul dan selanjutnya melakukan pewarnaan graf menggunakan algoritma Sequential dan algoritma Welch Powell. Hasil pewarnaan peta kota Makassar dengan menggunakan algoritma Sequential dan algoritma Welch Powell, sama-sama menghasilkan Bilangan kromatik $\chi(G)=4$ atau jumlah warna yang dihasilkan untuk mewarnai sebuah graf ada 4 warna. Warna yang digunakan yaitu merah, kuning, hijau, dan biru. Kemudian dari hasil pewarnaan graf ini dengan mudah dapat diaplikasikan untuk mewarnai peta kota Makassar berdasarkan ketentuan pewarnaan yang diperoleh. Karena memiliki Bilangan kromatik yang sama, maka dapat disimpulkan algoritma Sequential tidak lebih baik dari algoritma Welch Powell, ataupun sebaliknya algoritma Welch Powell tidak lebih baik dari algoritma Sequential untuk kasus pewarnaan peta kota Makassar. Adapun pewarnaan peta kota Makassar sebelumnya atau tanpa algoritma, menghasilkan bilangan kromatik $\chi(G)=12$ atau jumlah warna yang dihasilkan untuk mewarnai sebuah graf ada 12 warna. Sehingga kedua algoritma jauh lebih baik dalam melakukan pewarnaan dibandingkan pewarnaan peta kota Makassar sebelumnya atau tanpa algoritma.
\end{abstract}

Kata Kunci: Graf, Pewarnaan graf, Algoritma Sequential, Algoritma Welch Powell, bilangan kromatik 


\section{PENDAHULUAN}

Graf dapat digunakan untuk pada beberapa kasus, termasuk jejaring sosial, kimia, penjadwalan, pengiriman paket, navigasi satelit, teknik elektro,dan lain-lain [1]. Graf memiki aplikasi yang sangat luas, Salah satunya adalah pewarnaan graf (graph colouring). Banyak dari persoalan kehidupan sehari-hari yang memiliki karakterisitik seperti mewarnai graf. Contohnya adalah persoalan mewarnai peta sehingga tidak ada wilayah bertetangga yang mempunyai warna yang sama dan persoalan menentukan jadwal ujian mata kuliah sehingga tidak ada jadwal ujian yang bertabrakan

Kocay membagi Pewarnaan graf menjadi tiga macam, yaitu pewarnaan simpul, pewarnaan sisi, dan pewarnaan wilayah (region). Pewarnaan simpul (vertex coloring) adalah memberi warna pada simpul-simpul suatu graf sedemikian sehingga tidak ada dua simpul bertetangga mempunyai warna yang sama. Pewarnaan sisi (edge coloring) adalah memberi warna berbeda pada sisi yang bertetangga sehingga tidak ada dua sisi yang bertetangga mempunyai warna yang sama. Sedangkan pewarnaan bidang (region coloring) adalah memberi warna pada bidang sehingga tidak ada bidang yang bertetangga mempunyai warna yang sama [2]. Menurut Laputty, Pewarnaan bidang hanya bisa dilakukan dengan membuat graf tersebut menjadi graf planar terlebih dahulu [3].

Pada persoalan pewarnaan graf, masalah yang ada tidak hanya sekedar mewarnai simpul-simpul dengan warna berbeda dari warna simpul tetangganya saja, namun jumlah macam warna yang digunakan juga harus sesedikit mungkin. Jumlah warna minimum yang dapat digunakan untuk mewarnai simpul disebut bilangan kromatik graf $\mathrm{G}$ $(\chi(G))[4]$.

Beberapa graf tertentu dapat langsung ditentukan bilangan kromatiknya. Kosowsky \& Manuzewsky menjelaskan bilangan kromatik untuk berbagai graf, Untuk graf kosong, bilangan kromatiknya $\chi(G)=1$ karena semua simpul tidak terhubung, jadi untuk mewarnai semua simpul cukup dibutuhkan satu warna saja. Graf lengkap $K_{n}$ memiliki $\chi(G)=n \quad$ sebab semua simpul saling terhubung sehingga diperlukan $n$ buah warna. Graf bipartit mempunyai bilangan $\operatorname{kromatik} \chi(G)=2$, satu untuk simpul-simpul di himpunan $V_{1}$ dan satu lagi untuk simpul-simpul di himpunan $V_{2}$. Graf lingkaran dengan $n$ ganjil memiliki $\chi(G)=3$ sedangkan jika n genap maka $\chi(G)=2$, Sembarang pohon $\mathrm{T}$ memilik $\chi(G)=2$. Adapun untuk grafgraf lain tidak dapat dinyatakan secara umum kromatiknya. Sehingga batas untuk bilangan kromatik dari beberapa graf $\mathrm{G}$ dan dapat disimpulkan dengan $1 \leq \chi(G) \leq n[5]$.

Salah satu terapan penting pewarnaan graf adalah mewarnai peta. Ketika diminta mewarnai suatu peta yang terdiri atas sejumlah wilayah, wilayah pada peta dapat menyatakan provinsi, kabupaten, negara dan lain-lain. Untuk mudahnya perhatikan negara Amerika serikat yang terdiri atas 50 negara bagian. Dan diminta mewarnai setiap wilayah didalam peta sedemikian sehingga tidak ada dua wilayah bertetangga yang mempunyai warna yang sama. Satu cara untuk menjamin bahwa dua wilayah bertetangga tidak mempunyai warna yang sama adalah menggunakan warna yang berbeda untuk setiap wilayah.

Banyak algoritma yang dapat digunakan untuk mewarnai graf dalam berbagai penerapannya. Sari mengatakan teknik algoritma yang digunakan untuk melakukan pewarnaan graf secara umum mengadopsi metode First fit (FF), Largest Degree ordering (LDO), Saturation degree ordering (SDO), incidence degree ordering (IDO), dan lainlain [6].

Beberapa penelitian tentang penerapan dari pewarnaan graf yang pernah dilakukan sebelumnya yaitu [7] penggunaan algoritma greedy pada pewarnaan peta jawa timur, [8] Pewarnaan simpul dengan algoritma Welch Powell pada traffic light di Yogyakarta, [9] Implementasi algoritma tabu search pada penyusunan jadwal kuliah jurusan matematika UIN Alauddin Makassar, [10] Penyusunan lokasi duduk menggunakan algoritma greedy berbasis aplikasi visual basic, dan [11] Penggunaan algoritma sequential pada penataan buku perpustakaan, [12] penyelesaian pewarnaan graf dengan menggunakan algoritma genetika.

Penyelesaian algoritma yang akan digunakan pada penelitian ini yaitu algoritma Sequential dan algoritma Welch Powell. Algoritma Sequential merupakan algoritma paling sederhana karena pengerjaannya sesuai urutan simpul yang mengadopsi metode First fit (FF). Menurut Rahmat dkk, Implementasi algoritma Sequential diharapkan dapat menghasilkan banyaknya warna yang digunakan pada pewarnaan simpul graf mendekati atau sama dengan bilangan kromatik graf itu sendiri [13]. Sedangkan menurut Sari, Jika dilihat dari segi efisiennya, algoritma Sequential lebih efisien jika dibandingkan dengan algoritma lainnya. Karena algoritma Sequential memiliki kompleksitas waktu dan konpleksitas ruang yang lebih sedikit [14].

Adapun langkah-langkah algoritma Sequential dalam pewarnaan graf yaitu sebagai berikut: 
a) start

b) Input simpul (v) dan sisi (e)

c) Mencari nilai $L_{i}$ untuk setiap $i=1, \ldots, v$

d) Lakukan perulangan $i=1, \ldots, v$

e) Mencari nilai $C_{i}=V_{1}$ di $L_{i}$

f) Lakukan perulangan $j=1, \ldots, v$

g) Melakukan pengujian Jika $V_{i}, V_{j} \in E, i \neq j$ maka lanjutkan jika tidak kembali kelangkah (f)

h) Mencari nilai $L_{j}=L_{j}-C_{i}$

i) Output $V_{i} \cdot V_{v}=C_{i}$

j) Output $n=C_{v}$

k) End

Berdasarkan algoritma diatas maka dapat suatu flowchart sebagai berikut:

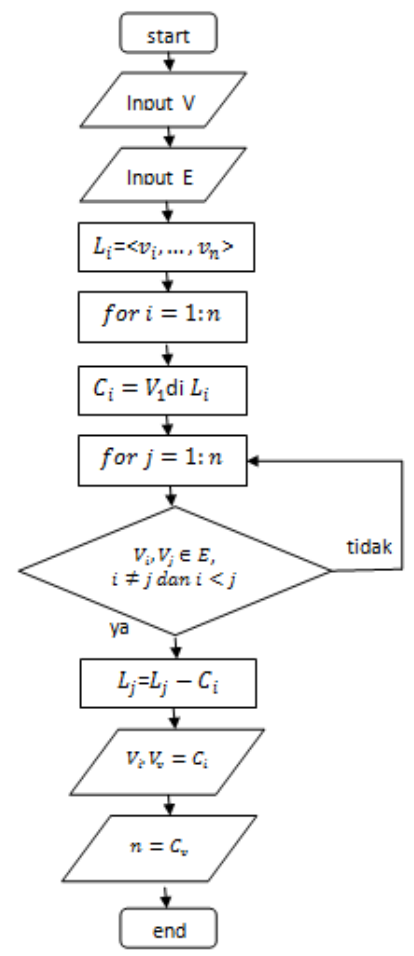

Gambar 1. Flowchart Algoritma Sequential

Adapun algoritma Welch Powell merupakan salah satu algoritma pewarnaan graf yang melakukan pewarnaan berdasarkan derajat tertinggi dari simpul-simpulnya yang mengadopsi metode Largest Degree Ordering (LDO). Menurut Ammar, algoritma ini dapat digunakan untuk mewarnai sebuah graf secara efisien [15]. Adapun menurut Purnamasari, mengatakan algoritma Welch Powell tidak selalu memberikan jumlah warna minimum yang diperlukan untuk mewarnai graf, tetapi algortima ini cukup praktis untuk digunakan dalam pewarnaan simpul sebuah graf dan hanya cocok digunakan untuk graf dengan orde yang kecil.
Adapun langkah-langkah dari Algoritma Welch Powell ini dinyatakan sebagai berikut :

a) Mendaftarkan simpul-simpul dalam graf G kemudian mengurutkan berdasarkan derajat yang tinggi ke rendah.

b) Menggunakan satu warna untuk mewarnai simpul pertama yang mempunyai derajat paling tinggi dan mewarnai pula simpul-simpul lain yang tidak bertetangga dengan simpul pertama sesuai daftar terurut .

c) Melakukan hal yang sama dengan langkah kedua yang memiliki derajat tertinggi berikutnya dalam daftar terurut yang masih belum diwarnai dengan menggunakan warna kedua yang berbeda dengan warna pertama.

d) Melakukan pewarnaan dan berhenti sampai semua simpul telah diwarnai.

Dari algoritma ini dapat dibuat flow chart sebagai berikut:

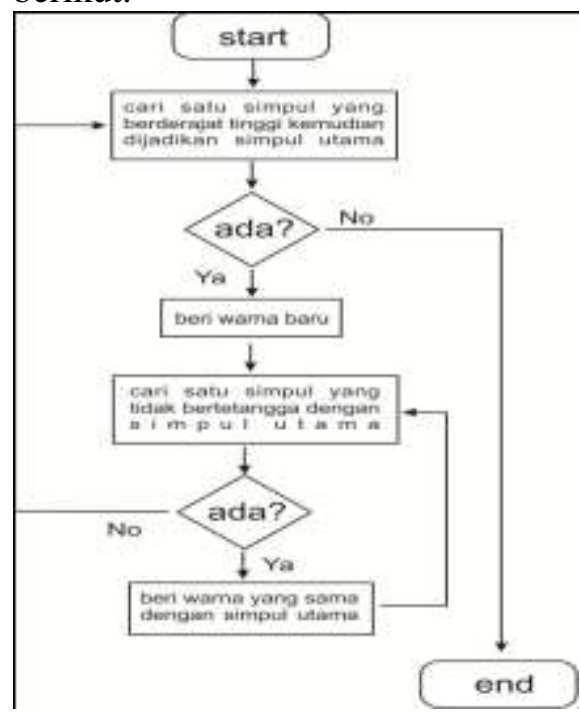

Gambar 2. Flowchart Algoritma Welch Powell

Selanjutnya untuk studi kasus sendiri peneliti tertarik untuk mewarnai peta kota makassar yang memiliki 14 kecamatan yang dijadikan wilayah (religion). Pemilihan kota Makassar dianggap dapat memberikan kasus yang baik untuk pewarnaan graf karena simpul yang tidak terlalu banyak juga tidak terlalu sedikit dan juga lokasi pengambilan data yang cukup dekat sehingga lebih memudahkan dalam melakukan penelitian.

\section{METODE PENELITIAN}

Metode penelitian yang digunakan oleh penulis adalah studi kasus yang bertujuan mengumpulkan informasi berupa peta kota Makassar yang didapatkan langsung dari kantor Dinas tata ruang kota Makassar atau yang berkaitan. 
Adapun Prosedur penelitian yang akan digunakan dalam mencapai tujuan penelitian adalah sebagai berikut:

1. Melakukan pewarnaan graf menggunakan Algoritma Sequential dengan menggunakan langkah-langkah sebagai berikut:

a. Mengumpulkan data atau informasi berupa peta Kota Makassar.

b. Menggambarkan ulang peta kota Makassar dengan menggunakan software Editing Corel Draw X7 dengan tanpa warna

c. Merepresentasikan peta kota Makassar kedalam bentuk graf dengan Wilayah kecamatan berupa Simpul (simpul) dan wilayah yang berdekatan dihubungkan oleh sebuah sisi

d. Menggunakan algoritma Sequential untuk melakukan pewarnaaan

2. Melakukan pewarnaan graf menggunakan Algoritma Welch Powell dengan menggunakan langkah-langkah sebagai berikut:

a. Mengumpulkan data atau informasi berupa peta Kota Makassar.

b. Menggambarkan ulang peta kota Makassar dengan menggunakan software Editing Corel Draw atau photoshop

c. Merepresentasikan peta kota Makassar kedalam bentuk graf dengan Wilayah kecamatan berupa Simpul (simpul) dan wilayah yang berdekatan dihubungkan oleh sebuah sisi.

d. Menggunakan algoritma Welch Powell untuk melakukan pewarnaaan

3. Membuat tabel perbandingan warna dan bilangan kromatik antara kedua algoritma dan juga pewarnaan sebelumnya.

\section{HASIL DAN PEMBAHASAN}

Berikut merupakan gambar peta kota Makassar

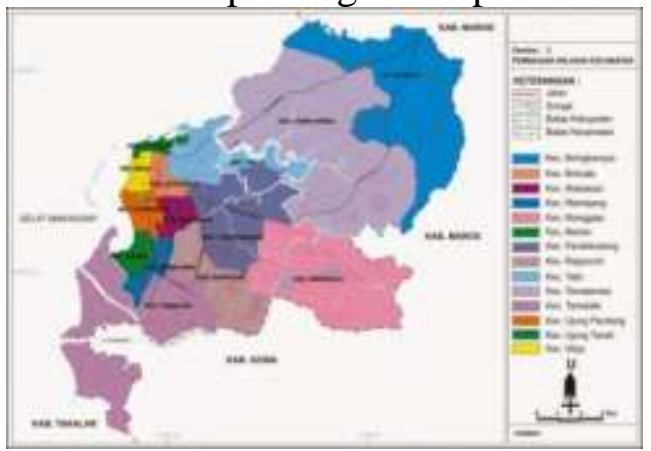

Gambar 3. Peta kota Makassar

Langkah selanjutnya yaitu menggambar ulang kembali peta dalam keadaan tanpa warna dan menginterpretasikan peta kedalam bentuk graf sebagai berikut:

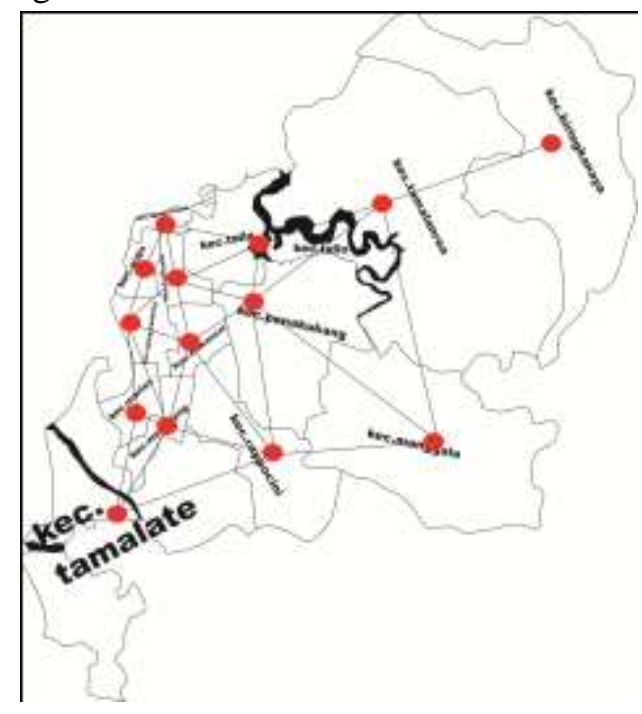

Gambar 4. Interpretasi peta kedalam graf

Sehingga didpatkan perbaikan bentuk graf sebagai berikut:

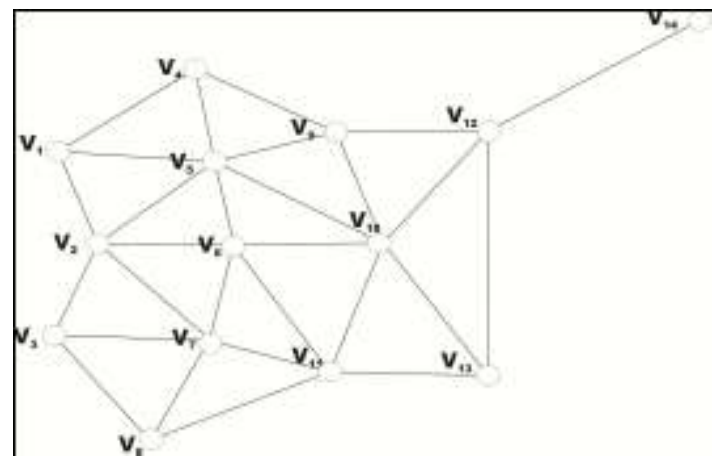

Gambar 5. Graf peta kota Makassar

Dimana :

$V_{1}=$ Kec.Wajo

$V_{2}=$ Kec.Ujung pandang

$V_{3}=$ Kec.Mariso

$V_{4}=$ Kec.Ujung Tanah

$V_{5}=$ Kec. Bontoala

$V_{6}=$ Kec.Makassar

$V_{7}=$ Kec.Mamajang

$V_{8}=$ Kec.Tamalate

$V_{9}=$ Kec.Tallo

$V_{10}=$ Kec.Panakukang

$V_{11}=$ Kec.Rappocini

$V_{12}=$ Kec.Tamalanrea

$V_{13}=$ Kec.Manggala

$V_{14}=$ Kec. Biringkanaya 
Langkah selanjutnya yaitu melakukan pewarnaan graf dengan menggunakan kedua algoritma yaitu algoritma Sequential dan Algoritma Welch Powell.

\section{Algoritma Sequential dalam menyelesaikan pewarnaan peta kota Makassar}

Langkah pertama dengan menggunakan algoritma ini yaitu menginput simpul (v) dan (e) yang ada dalam Graf $G=(E, V)$

$V=\left\{V_{1}, V_{2}, V_{3}, V_{4}, V_{5}, V_{6}, V_{7}, V_{8}, V_{9}, V_{10}, V_{11}, V_{12}, V_{13}, V_{14}\right\}$

$E=\left\{\begin{array}{c}\left(V_{1}, V_{2}\right),\left(V_{1}, V_{4}\right),\left(V_{1}, V_{5}\right),\left(V_{2}, V_{3}\right),\left(V_{2}, V_{5}\right),\left(V_{2}, V_{6}\right),\left(V_{2}, V_{7}\right),\left(V_{3}, V_{7}\right),\left(V_{3}, V_{8}\right) \\ \left(V_{4}, V_{5}\right),\left(V_{4}, V_{9}\right),\left(V_{5}, V_{6}\right),\left(V_{5}, V_{9}\right),\left(V_{5}, V_{10}\right),\left(V_{6}, V_{7}\right),\left(V_{6}, V_{10}\right),\left(V_{6}, V_{11}\right),\left(V_{7}, V_{8}\right) \\ \left(V_{7}, V_{11}\right),\left(V_{8}, V_{11}\right),\left(V_{9}, V_{10}\right),\left(V_{9}, V_{12}\right),\left(V_{10}, V_{11}\right),\left(V_{10}, V_{12}\right),\left(V_{10}, V_{13}\right),\left(V_{11}, V_{13}\right) \\ \left(V_{13}, V_{13}\right),\left(V_{12}, V_{14}\right)\end{array}\right\}$

Adapun nilai $L_{i}$ untuk setiap $i=1, \ldots, 14$

$L_{1}=\langle 1\rangle$

$L_{2}=\langle 1,2\rangle$

$L_{3}=\langle 1,2,3\rangle$

$L_{4}=\langle 1,2,3,4\rangle$

$L_{5}=\langle 1,2,3,4,5\rangle$

$L_{6}=\langle 1,2,3,4,5,6\rangle$

$L_{7}=\langle 1,2,3,4,5,6,7\rangle$

$L_{8}=\langle 1,2,3,4,5,6,7,8\rangle$

$L_{9}=\langle 1,2,3,4,5,6,7,8,9\rangle$

$L_{10}=\langle 1,2,3,4,5,6,7,8,9,10\rangle$

$L_{11}=\langle 1,2,3,4,5,6,7,8,9,10,11\rangle$

$L_{12}=\langle 1,2,3,4,5,6,7,8,9,10,11,12\rangle$

$L_{13}=\langle 1,2,3,4,5,6,7,8,9,10,11,12,13\rangle$

$L_{14}=\langle 1,2,3,4,5,6,7,8,9,10,11,12,13,14\rangle$

Langkah berikutnya yaitu melakukan perulangan dari $i=1$ sampai 14 dan $j=1$ sampai 14 untuk melakukan update $L_{i}$ setiap kali perulangan dan mendapatkan nilai $C_{i}$. Dari perhitungan diatas maka diperoleh warna setiap simpulnya yaitu $C_{1}=1$, $C_{2}=2, C_{3}=1, C_{4}=2, C_{5}=3, C_{6}=1, C_{7}=3$, $C_{8}=2, C_{9}=1, C_{10}=2, C_{11}=4, C_{12}=3, C_{13}=$ 1 , dan $C_{14}=2$.

Dari sini dapat diperoleh warna masing-masing simpul yaitu $V_{1}=1, V_{2}=2, V_{3}=1, V_{4}=2, V_{5}=$ $3, V_{6}=1, V_{7}=3, V_{8}=2, V_{9}=1, V_{10}=2, V_{11}=$ $4, V_{12}=3, V_{13}=1$ dan $V_{14}=2$. Misalkan kita beri 1 untuk warna merah, 2 untuk warna kuning, 3 untuk warna hijau, 4 untuk warna biru, maka diperoleh graf dan peta yang telah diwarnai sebagai berikut;

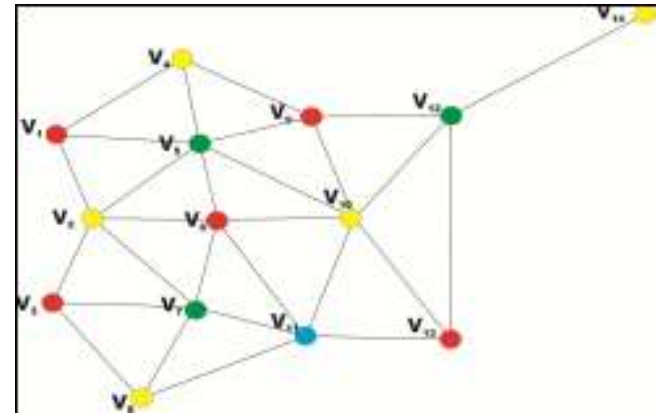

Gambar 6. Graf peta kota Makassar yang telah diwarnai dengan Algoritma Sequential

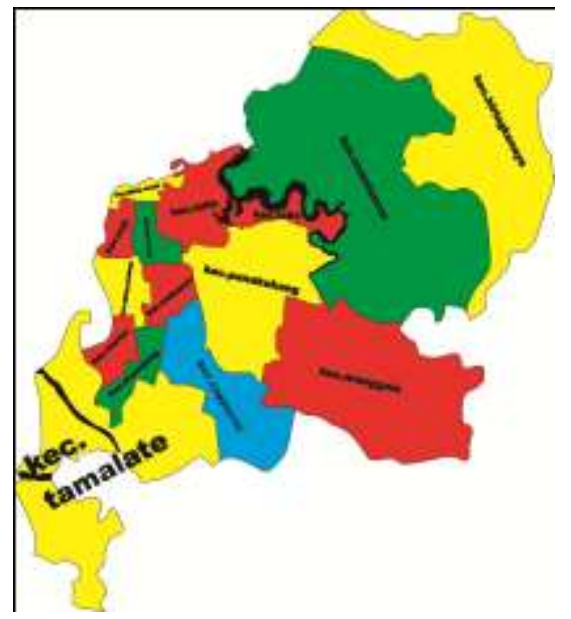

Gambar 7. Peta kota Makassar yang telah diwarnai

\section{Algoritma Welch Powell dalam menyelesaikan pewarnaan peta kota Makassar}

Adapun langkah-langkah dari Algoritma Welch-Powell yang pertama adalah mendaftarkan simpul-simpul dalam graf beserta tetangga dan derajatnya.

Tabel 1.Simpul dalam graf beserta tetangga dan derajatnya

\begin{tabular}{|l|c|c|c|}
\hline No & Simpul & Tetangga & Derajat \\
\hline 1 & $V_{1}$ & $V_{2}, V_{4}, V_{5}$ & 3 \\
\hline 2 & $V_{2}$ & $V_{1}, V_{3}, V_{5}, V_{6}, V_{7}$ & 5 \\
\hline 3 & $V_{3}$ & $V_{2}, V_{7}, V_{8}$ & 3 \\
\hline 4 & $V_{4}$ & $V_{1}, V_{5}, V_{9}$ & 3 \\
\hline 5 & $V_{5}$ & $V_{1}, V_{2}, V_{4}, V_{6}, V_{9}, V_{10}$ & 6 \\
\hline 6 & $V_{6}$ & $V_{2}, V_{5}, V_{7}, V_{10}, V_{11}$ & 5 \\
\hline 7 & $V_{7}$ & $V_{2}, V_{3}, V_{6}, V_{8}, V_{11}$ & 5 \\
\hline 8 & $V_{8}$ & $V_{3}, V_{7}, V_{11}$ & 3 \\
\hline 9 & $V_{9}$ & $V_{4}, V_{5}, V_{10}, V_{12}$ & 4 \\
\hline 10 & $V_{10}$ & $V_{5}, V_{6}, V_{9}, V_{11}, V_{12}, V_{13}$ & 6 \\
\hline 11 & $V_{11}$ & $V_{6}, V_{7}, V_{8}, V_{10}, V_{13}$ & 5 \\
\hline 12 & $V_{12}$ & $V_{9}, V_{10}, V_{14}$ & 3 \\
\hline 13 & $V_{13}$ & $V_{10}, V_{11}, V_{12}$ & 3 \\
\hline 14 & $V_{14}$ & $V_{12}$ & 1 \\
\hline
\end{tabular}


Selanjutnya mengurutkan berdasarkan derajat yang tinggi ke rendah

Tabel 2.Urutan simpul berdasarkan derajat terbesar ke terkecil

\begin{tabular}{|l|c|c|c|}
\hline No & Simpul & Tetangga & Derajat \\
\hline 1 & $V_{5}$ & $V_{1}, V_{2}, V_{4}, V_{6}, V_{9}, V_{10}$ & 6 \\
\hline 2 & $V_{10}$ & $V_{5}, V_{6}, V_{9}, V_{11}, V_{12}, V_{13}$ & 6 \\
\hline 3 & $V_{2}$ & $V_{1}, V_{3}, V_{5}, V_{6}, V_{7}$ & 5 \\
\hline 4 & $V_{6}$ & $V_{2}, V_{5}, V_{7}, V_{10}, V_{11}$ & 5 \\
\hline 5 & $V_{7}$ & $V_{2}, V_{3}, V_{6}, V_{8}, V_{11}$ & 5 \\
\hline 6 & $V_{11}$ & $V_{6}, V_{7}, V_{8}, V_{10}, V_{13}$ & 5 \\
\hline 7 & $V_{9}$ & $V_{4}, V_{5}, V_{10}, V_{12}$ & 4 \\
\hline 8 & $V_{12}$ & $V_{9}, V_{10}, V_{13}, V_{14}$ & 4 \\
\hline 9 & $V_{1}$ & $V_{2}, V_{4}, V_{5}$ & 3 \\
\hline 10 & $V_{3}$ & $V_{2}, V_{7}, V_{8}$ & 3 \\
\hline 11 & $V_{4}$ & $V_{1}, V_{5}, V_{9}$ & 3 \\
\hline 12 & $V_{8}$ & $V_{3}, V_{7}, V_{11}$ & 3 \\
\hline 13 & $V_{13}$ & $V_{10}, V_{11}, V_{12}$ & 3 \\
\hline 14 & $V_{14}$ & $V_{12}$ & 1 \\
\hline
\end{tabular}

Menggunakan satu warna pertama misalkan warna merah untuk mewarnai simpul pertama yaitu $V_{5}$ yang mempunyai derajat paling tinggi dan simpulsimpul lain yang tidak bertetangga dengan simpul pertama atau simpul yang telah terpilih dengan urutan berdasarkan derajat tertinggi

$V_{5}=$ warna merah

$V_{10}=$ tidak diberi warna karena bertetangga dengan $V_{5}$

$V_{2}=$ tidak diberi warna karena bertetangga dengan $V_{5}$

$V_{6}=$ tidak diberi warna karena bertetangga dengan $V_{5}$

$V_{7}=$ warna merah

$V_{12}=$ warna merah

$V_{11}=$ tidak diberi warna karena bertetangga dengan $V_{7}$

$V_{9}=$ tidak diberi warna karena bertetangga dengan $V_{5}$

$V_{1}=$ tidak diberi warna karena bertetangga dengan $V_{5}$

$V_{3}=$ tidak diberi warna karena bertetangga dengan $V_{7}$

$V_{4}=$ tidak diberi warna karena bertetangga dengan $V_{5}$

$V_{8}=$ tidak diberi warna karena bertetangga dengan $V_{7}$
$V_{13}=$ tidak diberi warna karena bertetangga dengan $V_{12}$

$V_{14}=$ tidak diberi warna karena bertetangga dengan $V_{12}$

Langkah selanjutnya yaitu melakukan hal yang sama dengan langkah sebelumnya yang memiliki derajat tertinggi berikutnya dalam daftar terurut yang masih belum diwarnai dengan menggunakan warna kedua yaitu warna kuning. Setelah semua simpul selesai diwarnai maka diperoleh warna simpul $V_{5}, V_{7}, V_{12}$ berwarna merah, simpul $V_{2}, V_{4}, V_{8}, V_{10}, V_{14}$ berwarna kuning, simpul $V_{1}, V_{3}, V_{6}, V_{9}, V_{13}$ berwarna hijau, dan simpul $V_{11}$ berwarna biru sehingga dapat diberi pewarnaan pada graf dan peta sebagai berikut:

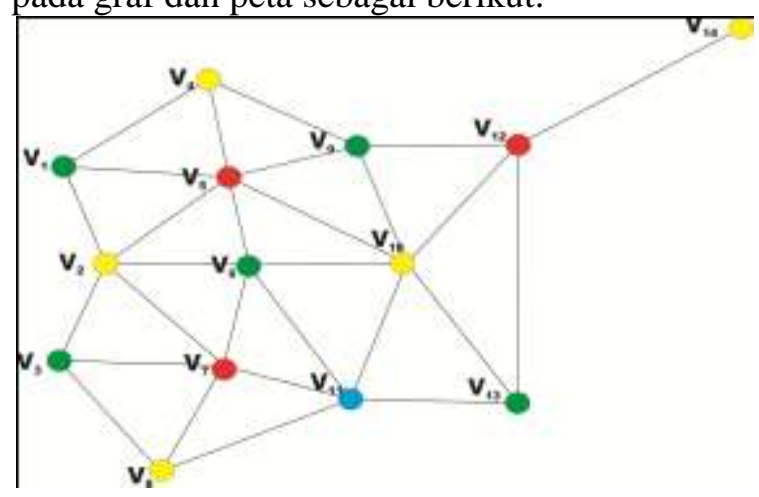

Gambar.8. Graf peta kota Makassar yang telah diwarnai dengan Algoritma Welch Powell

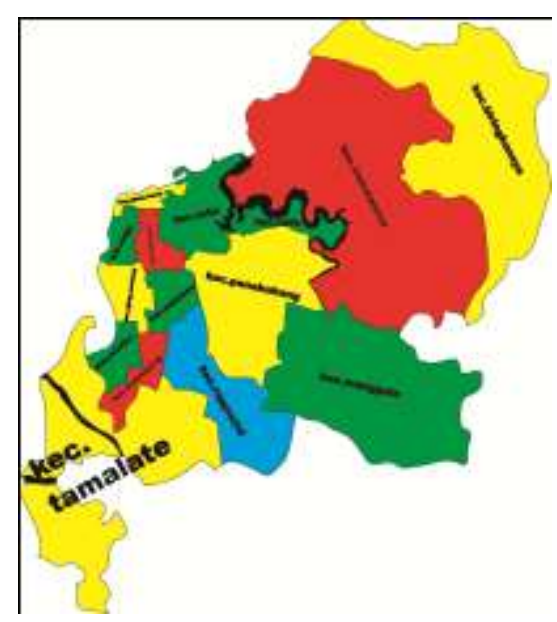

Gambar 9. Peta kota Makassar yang telah diwarnai dengan Algoritma Welch Powell 
Tabel 3. pewarnaan peta berdasarkan kedua algoritma dan warna sebelumnya

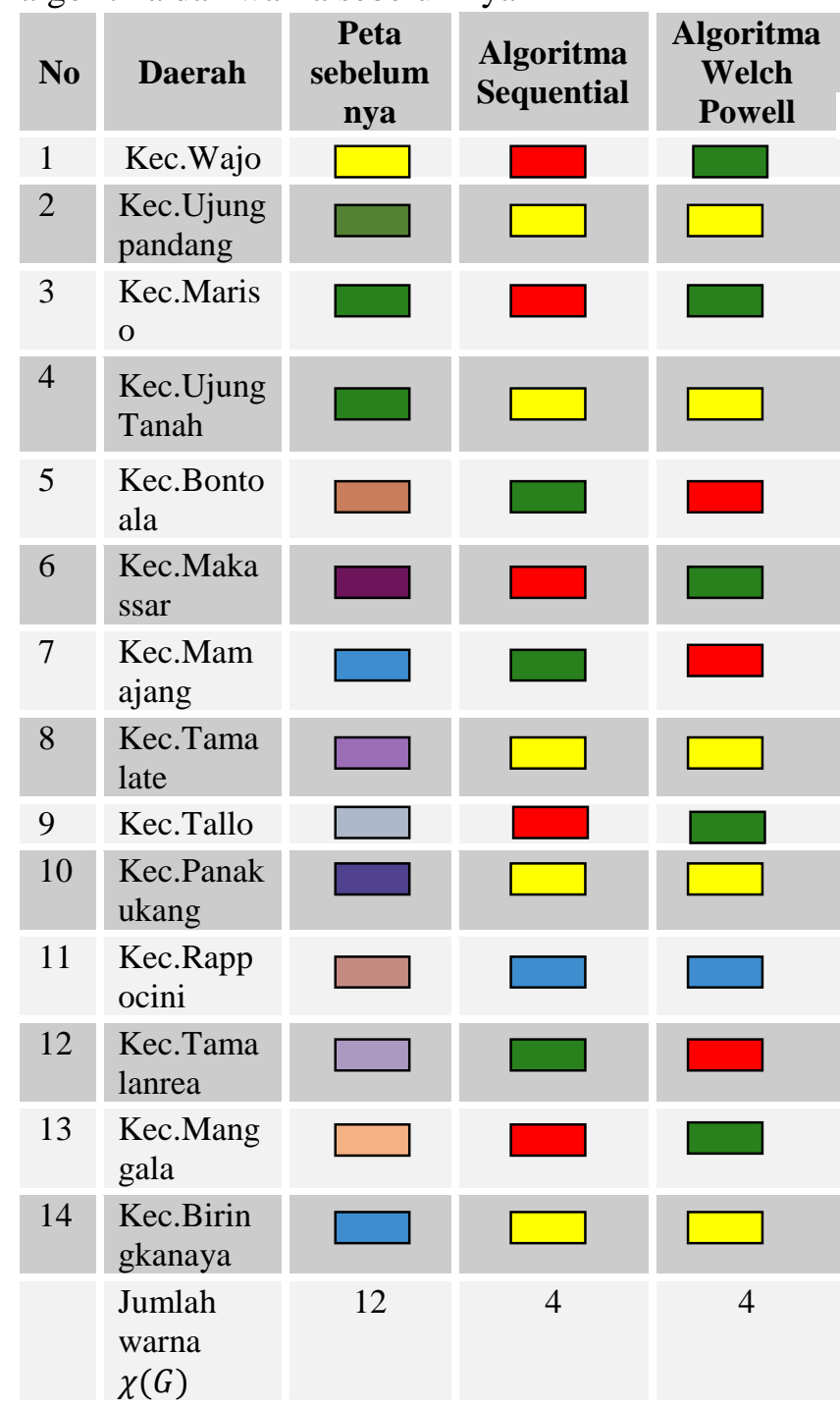

Berdasarkan Tabel 3 diperoleh perbandingan warna untuk setiap kecamatan, dimana pada pewarnaan peta dengan menggunakan kedua algoritma yaitu algoritma Sequential dan Welch Powell, sama-sama menghasilkan bilangan kromatik $\chi(G)=4$. Karena memiliki Bilangan kromatik yang sama maka Algoritma Sequential tidak lebih baik dari Algoritma Welch Powell, ataupun sebaliknya Algoritma Welch Powell tidak lebih baik dari Algoritma Sequential untuk kasus pewarnaan peta pada kota Makassar. Adapun pada pewarnaan peta sebelumnya atau tanpa menggunakan algoritma yaitu menghasilkan jumlah warna atau $\chi(G)=12$. Pada penggunaan algoritma Sequential dan Welch Powell, keduanya jauh lebih efektif karena warna yang digunakan sedikit sehingga hanya perlu menggunakan warna-warna popular seperti merah, kuning, biru dan hijau. Sedangkan pada pewarnaan peta sebelumnya, selain menggunakan warna-warna popular juga memungkinkan untuk menggunakan warna-warna gradasi disebabkan banyaknya warna yang harus digunakan.

IV. KESIMPULAN DAN SARAN

Kesimpulan dari penelitian ini adalah Algoritma Sequential dapat diimplementasikan untuk mewarnai peta kota Makassar. Pada algoritma Sequential diperoleh warna untuk masing-masing daerah yaitu kec.Wajo berwarna merah, kec.ujung pandang berwarna kuning, kec.mariso berwarna merah, kec.ujung tanah berwarna kuning, kec.bontoala berwarna hijau, kec.makassar berwarna merah, kec.mamajang berwarna hijau, kec.tamalate berwarna kuning, kec.tallo berwarna merah, kec.panakukang berwarna kuning, kec.rappocini berwarna biru, kec.tamalanrea berwarna hijau, kec.manggala berwarna merah, kec.biringkanaya berwarna kuning.

Begitupun dengan Algoritma Welch Powell dapat diimplementasikan untuk mewarnai peta kota Makassar. Pada algoritma Welch Powell diperoleh warna untuk masing-masing daerah yaitu kec.Wajo berwarna hijau, kec.ujung pandang berwarna kuning, kec.mariso berwarna hijau, kec.ujung tanah berwarna kuning, kec.bontoala berwarna merah, kec.makassar berwarna hijau, kec.mamajang berwarna merah, kec.tamalate berwarna kuning, kec.tallo berwarna hijau, kec.panakukang berwarna kuning, kec.rappocini berwarna biru, kec.tamalanrea berwarna merah, kec.manggala berwarna hijau, kec.biringkanaya berwarna kuning.

Pada algoritma Sequential dan algoritma Welch Powell sama-sama menghasilkan Bilangan kromatik $\chi(G)=4$. Kedua algoritma juga jauh lebih efektif dibandingkan pewarnaan peta sebelumnya atau tanpa algoritma dimana menghasilkan jumlah warna atau Bilangan kromatik $\chi(G)=12$.

Adapun saran untuk penelitian berikutnya yaitu mewarnai peta yang lebih kompleks yakni memiliki region (wilayah ) yang lebih banyak dan menggunakan algoritma lain untuk melakukan pewarnaan

\section{DAFTAR PUSTAKA}

[1] R. M. R. Lewis, A Guide to Graph Colouring. 2016.

[2] W. Kocay and D. L. Kreher, Graphs, algorithms, and optimization. 2017.

[3] Assma Laputty, "Penggunaan Metode Greedy Pada Pengaturan Lampu Lalu Lintas Jalan Di Perempatan Al-Fatah Ambon Dengan Teori Graph," J. Pros. 
Konfrensi Nas. Ilmu Komput. (KONIK, Vol. 2, pp. 147-151, 2014.

[4] R. Munir, Matematika Disktrit. Bandung: Informatika Bandung, 2010.

[5] A. Kosowski and K. Manuszewski, "Classical coloring of graphs," pp. 1-19, 2004.

[6] K. P. Sari, "Perbandingan Algoritma Pewarnaan LDO, SDO, dan IDO pada Graf Sederhana."

[7] F. Ardiansyah and M. Syaifullah, "Implementasi Algoritma Greedy Untuk Melakukan Graph Coloring: Studi Kasus Peta Propinsi Jawa Timur," J. Inform., 2012.

[8] A. M. Soimah and N. S. M. Mussafi, "Pewarnaan Simpul Dengan Algoritma Welch-Powell Pada Traffic Light Di Yogyakarta," J. Fourier, vol. 2, no. 2, p. 73, 2013.

[9] Binti Ida Umaya, "Implementasi Algoritma Tabu Search Dalam Pewarnaan Simpul Graf (STUDI KASUS : Penjadwalan mata kuliah jurusan matematika fakultas sains dan teknologi UIN Alauddin Makassar)," Univ. Nusant. PGRI Kediri, vol. 1, pp. 17, 2017.

[10] H. Turosdiah, Armiati, and M. P. Dewi, "Penerapan Pewarnaan Titik pada Graf dalam Penyusunan Lokasi Duduk Menggunakan Algoritma Greedy Berbantuan Microsoft Visual Basic 6.0," UNP J. Math., vol. 2, no. 1, 2014.

[11] N. Selma Karamy, "Pewarnaan Titik Pada Graf Dengan Menggunakan Algoritma Pewarnaan Barisan Sederhana Dalam Penataan Buku Perpustakaan," in Conference on Research \& Community Services, 2019, pp. 557-565.

[12] T. S. N. Anggraini, Lana Aristya, Rosyida, Isnaini ,Asih, "Penyelesaian Masalah Pewarnaan Graf Dengan Algoritma Genetika," vol. 8, no. 1, pp. 30-39, 2019.

[13] R. J. Noor, H. Hendra, and W. Powell, "Implementasi Algoritma Baris dalam Pewarnaan Titik pada Graf Sederhana
Implementation of Sequent Algorithm in Coloring Vertex on Simple Graph," vol. 1, no. 1, pp. 19-22, 2013.

[14] P. Studi and T. Informatika, "Perbandingan Algoritma," no. 13512025, pp. 1-13, 2014.

[15] M. Ammar, "Penyusunan Jadwal Ujian Mata Kuliah Semester V Jurusan Matematika Uin Alauddin Makassar," pp. 299-303. 